\title{
SOME ASPECTS OF EPIDEMICS AND GERMAN ART ABOUT 1500
}

\author{
by
}

\section{R. F. TIMKEN-ZINKANN}

IT IS a well-known fact that the bubonic plague was the source of many works of painting, sculpture, graphic arts and architecture and that it was the theme of important works of literature and drama from the fourteenth century to the baroque period. Like all communal catastrophes since time immemorial, the plague was held to be the wages of individual or communal sin. Expiation, invocation of the Deity and of the saints (among whom St. Sebastian and St. Roche were believed to be the most effective intercessors) and gratitude for deliverance from the affliction were the principal motives for such artistic manifestations. Often such works were commissioned in fulfilment of vows made during the raging of the plague. As may be expected, many works made to order were pedestrian; but a number of great monuments of the arts are witnesses of the impression the plague made in its time.

The opinion has been rather popular in Germany that the Isenheim Altar, the work of Mathias Neithart, also called Grünewald, was a 'plague altar'. However, this outstanding work is undoubtedly related to another epidemic, St. Anthony's Fire, an affliction caused by a fungus attacking rye and leading to very painful infections of the skin, gangrene of the extremities and neurological disturbances. Admittedly no document regarding the commission of the Isenheim Altar has been found, but we know that it was ordered by the Sicilian-born preceptor of the Monastery of the Antonites in Isenheim, Guido Guersi, and was completed in 1514. For centuries the monastery maintained a hospital for those afflicted by St. Anthony's Fire in the little town south of Colmar and, soon after the outbreak of syphilis in Alsace in the middle 1490s, it also accepted syphilitic patients. One of the panels of the Isenheim Altar, 'The Temptation of St. Anthony', shows at the lower left side a reclining figure called the 'Devil of St. Anthony's Fire' (Figure 2), with a swollen abdomen; the greenish skin is covered with pustules and wounds, and the hands are already mutilated. Lucien Sittler, the Director of the Municipal Archives of Colmar, in his work Der Isenheimer Altar (Colmar, n.d.), believes that the position of this devil perhaps alludes also to syphilis. The front panel of the altar shows the crucified Christ (Figure 1) whose body is covered with many wounds of the flagellation. Sittler reports that the patients when entering the hospital were brought before this representation of the crucifixion to contemplate the suffering of Christ. This very strong and realistic painting in its expression of extreme pain and suffering, shocks and terrifies the beholder even in our day. The entire work of Grünewald with its strong composition and beauty of colour places Master Mathias Neithart among the great masters of European painting, although only a few other works can be identified as by him.

Excepting the possible allusion to syphilis in the figure of the 'Devil of St. Anthony's 


\section{R. F. Timken-Zinkann}

Fire' we rarely find works of art which we can connect directly with syphilis, although those inspired by the bubonic plague are abundant. The reasons appear to be obvious. The plague struck cities and regions with great vehemence for a few months' duration, leaving untold numbers of dead, but syphilis was considered more of a 'private' disease. Since the mode of contagion became known within a short time, God's penalty for individual offence was held responsible for the affliction rather than the wrath of God for communal sin. It is quite possible that votive works of art were commissioned by those afflicted, who did not, however, make their private misery public. The fact that St. Sebastian and St. Roche were also patron saints of the syphilitic suggests that some representations of these saints have been erroneously considered to have been occasioned by outbreaks of the plague.

A certain contradiction in public opinion regarding the causes of syphilis can be witnessed at the Diet of Worms which convened in August 1495. The Edict against Blasphemy, the first known printed reference to syphilis, describes this disease as God's penalty for the abuse of his name. ${ }^{1}$ At the same Diet the humanist Jacob Wimpheling presented his poem to Maximilian I in which he deplored the outbreak of the new epidemic; he petitioned the Emperor to close the brothel of Schlettstedt, Wimpheling's native town near Strassburg. ${ }^{2}$ Both documents must have been drafted during the first half of 1495 and refer to the fact that the new affliction had attacked many German cities. Wimpheling's more realistic opinion appears to have been accepted rapidly, as witnessed by the edicts of German cities, dated 1496, closing bath-houses and brothels.

On the other hand, the first printed medical paper on syphilis, a broadsheet of 1496 by the Nüremberg town physician Dietrich Ulsen (Figure 3) refers to the great conjunction of 1484 and ascribes the outbreak of syphilis to astrological influences. This broadsheet was illustrated by no less a personality in German art than Albrecht Dürer (1471-1529), though the artistic qualities of Dürer's woodcut appear as little inspired as the verses it illustrates.

Only two years before, after his travels as a journeyman, Dürer had returned to Nüremberg to establish himself as an independent master painter and to marry. Already his works of 1495 show a profusion of creative invention that are characteristic of the first five years of his life as an independent master. None of this is reflected in the commissioned illustration of Dietrich Ulsen's broadsheet of 1496.

It appears noteworthy that some of Dürer's finest graphic work of this period between 1494 and 1503 deals with a theme which may be related to the cause of syphilis, a theme that may be described as the 'Woman, Death and Devil Syndrome', the iconographic connection of couples or women with death or the devil. The chronological coincidence of the outbreak of syphilis with the origin of Dürer's iconographic theme points to this relation. The Dances of Death, of which examples abound after the outbreak of the plague, treat of the theme that death knows no distinction of worldly status, class, age or sex. Dürer's works concentrate on the connection between Lust, Death and the Devil. His well-known works dealing with this thematic connection are:

The Pleasures of the World (W 163, P 874, Ashmolean Museum, Oxford), drawing, probably 1494 


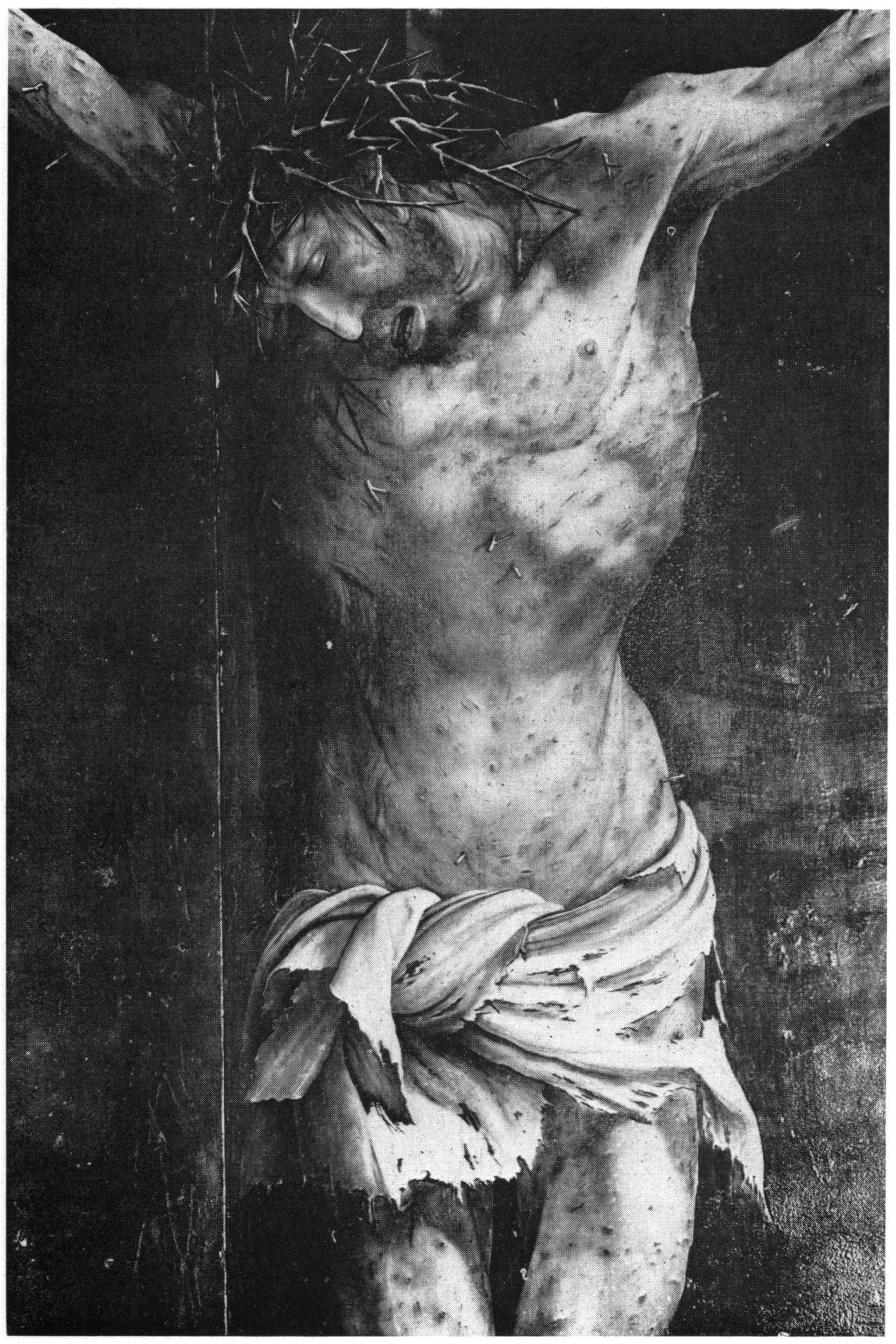

Figure 1.

Mathis Neidhart, called Grünewald, The Isenheim Altar. Detail of the front panel: The Crucifixion. Photograph by Charles Fellmann, Musée Unterdenlinden, Colmar. 


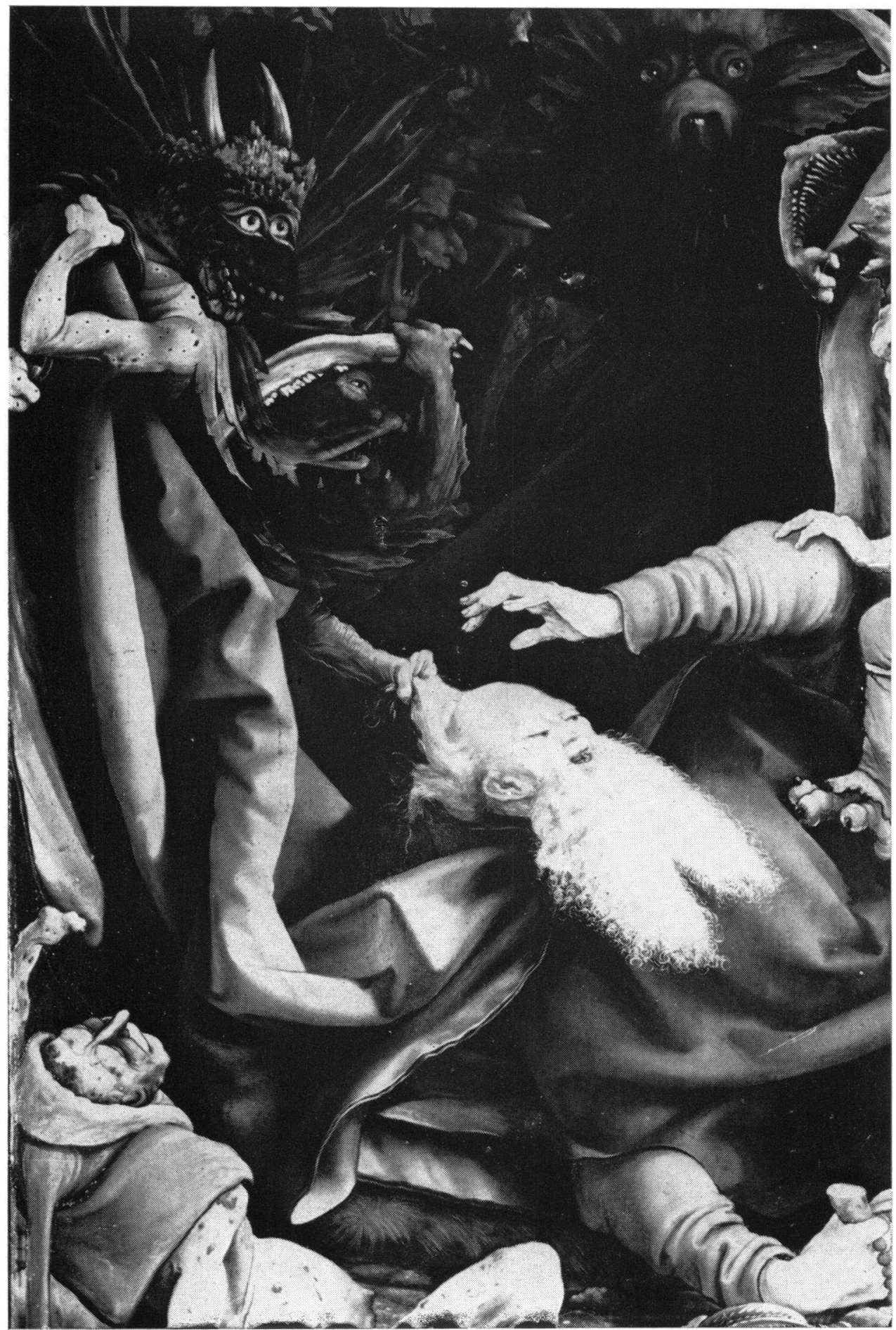

Figure 2.

Mathis Neidhart, called Grünewald, Panel of the Isenheim Altar: The Temptation of St. Anthony. At lower left side: The Devil of St. Anthony's Fire. Photograph by Charles Fellmann, Musée Unterdenlinden, Colmar. 

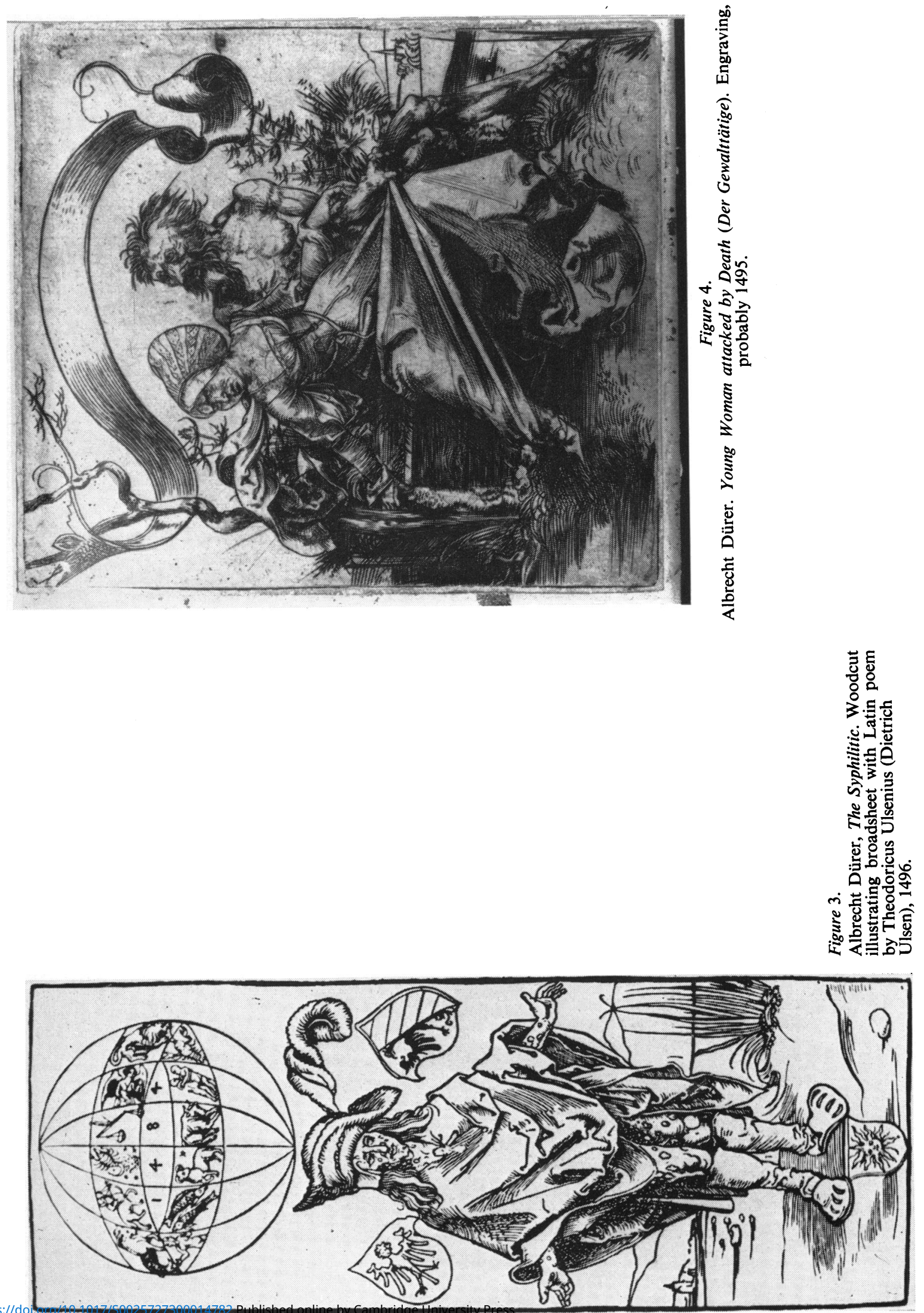

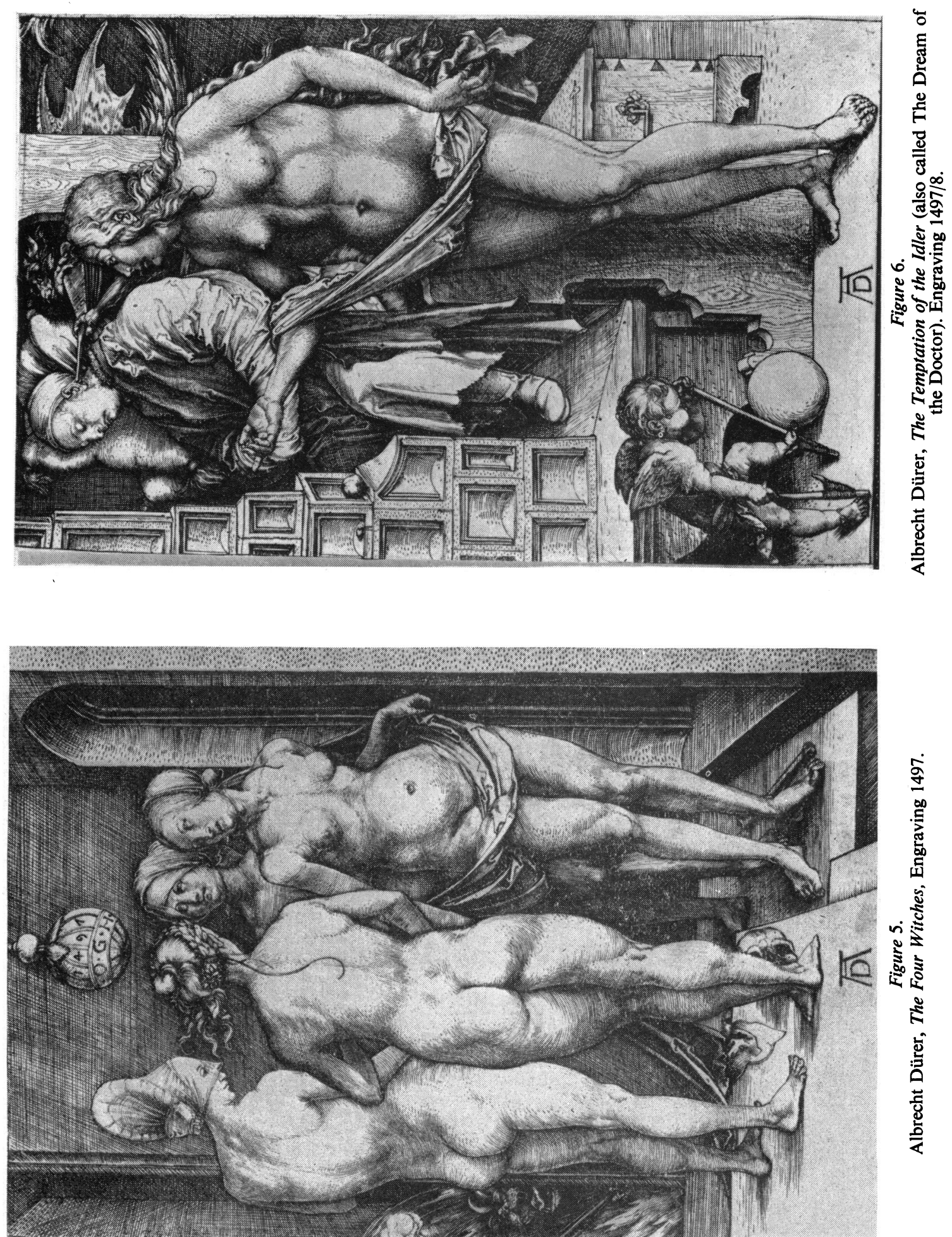

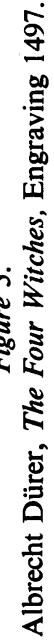



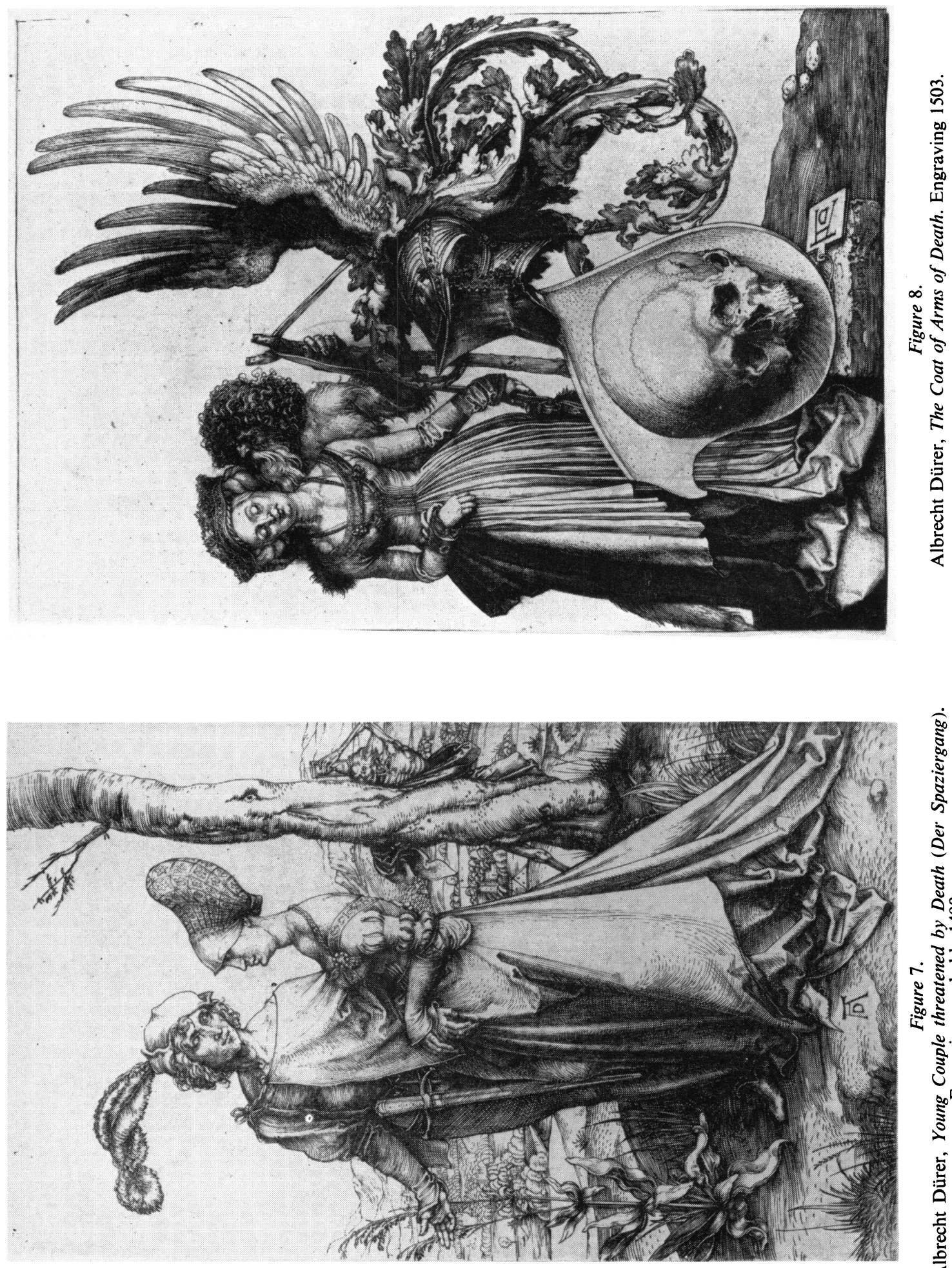

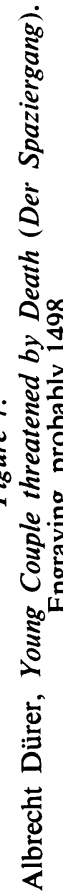



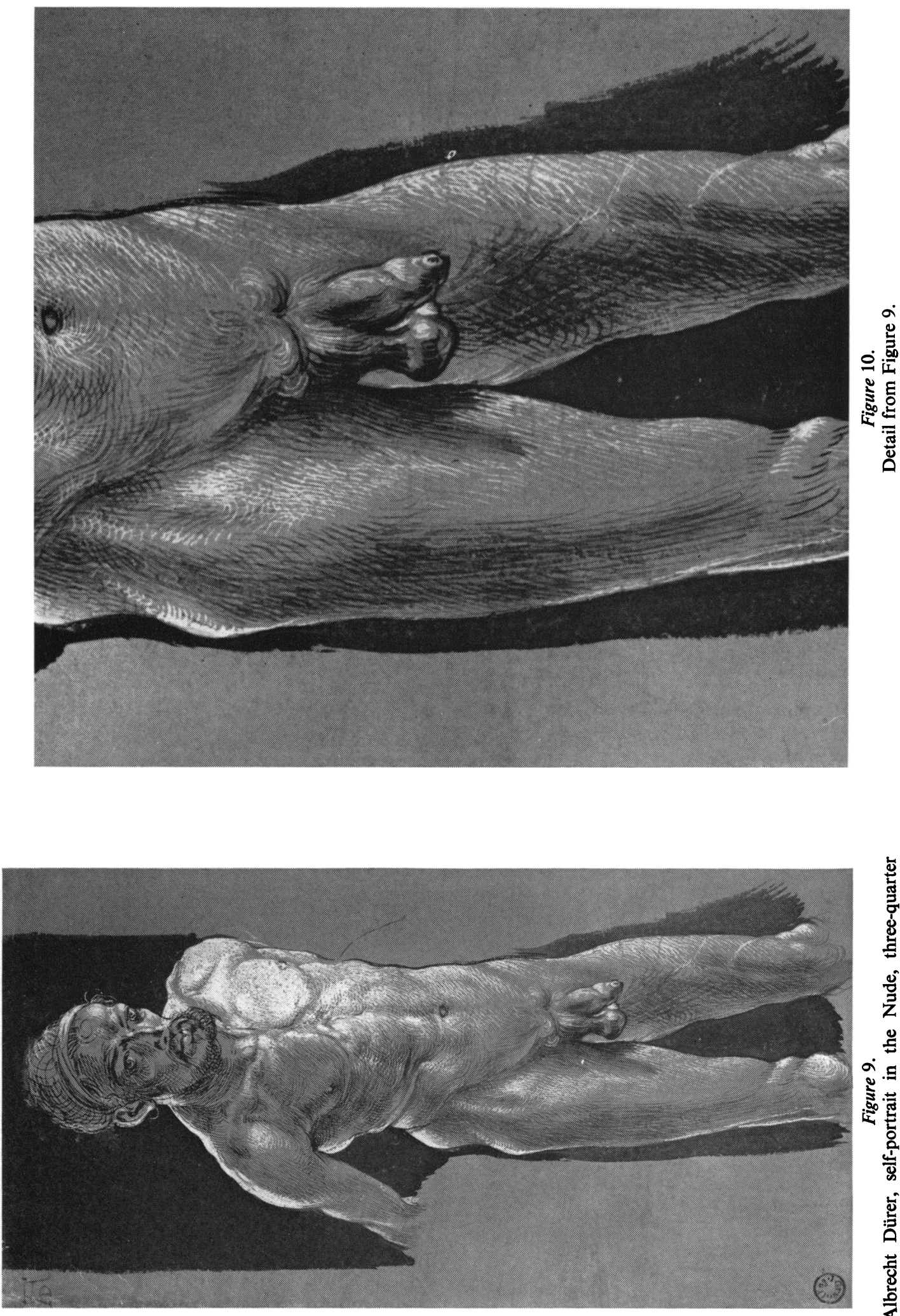

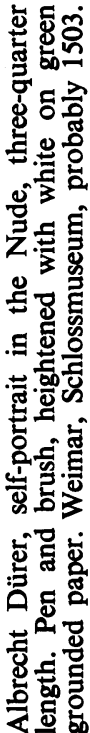




\title{
Some Aspects of Epidemics and German Art about 1500
}

\author{
Young Woman attacked by Death (Figure 4), engraving, 1495 \\ The Four Witches (Figure 5), engraving 1497 \\ The Temptations of the Idler (Figure 6), engraving 1497-8 \\ Young Couple threatened by Death (Figure 7), engraving, 1498 \\ The Coat of Arms of Death (Figure 8), engraving 1503
}

While 'The Pleasures of the World' may still have been influenced by the Dances of Death, the five engravings have a distinctly different theme from that of the customary former representations. The most frightening one is the engraving of 1495 , bordering on the obscene, showing the rape of a young woman by Death. No German artist prior to Dürer dared to show such a subject and to shock the viewer in such a manner.

Human nature somehow adjusts to the greatest terrors and it is no wonder that the engravings in their chronological order appear to mellow in their fear of Death and the Devil. 'The Four Witches' of 1497 are rather frightening in their connection with witchcraft and superstition, whereas the 'Young Couple taking a Walk' (1498) counterpoises a rather pleasant environment to the fear of death; the 'Dream of the Idler' assumes humorous overtones and finally 'The Weapon with the Skull' (1503) is tempered by heraldic formality.

The antecedents of two engravings may indicate our hypothesis of the influence of syphilis on the iconographic contents. A drypoint by an unknown master, probably from the Lower Rhine at the beginning of the 1490s, appears to be closely related to the figures of the nude women and their grouping in 'The Four Witches'. This prototype shows neither devil nor death, but in Dürer's engraving the devil appears to lie in wait.

An early drypoint 'Youth and Death' by the Housebook Master is apparently related to the theme of the Dances of Death common to the high Middle Ages. It shows a young dandy upon whose shoulder Death lays his hand. The male figure in Dürer's drawing of 1492/3, 'Young Couple taking a Walk', is evidently influenced by the drypoint of the Housebook Master, but the young man shows Dürer's features. This idyllic and innocent representation of two lovers promenading is in pointed contrast to the engraving of 1498, 'Young Couple theatened by Death'. Here we recognize again the young Dürer's face; a somewhat aggressive woman with not very attractive features approaches the young man; behind a tree lurks Death. The stroll of the young lovers has assumed terrifying aspects.

A literary reference to the connection between Voluptas and Death, very probably known to Dürer, had indeed already been made by Sebastian Brant in his Ship of Fools published in 1494, ${ }^{3}$ illustrated by Dürer. Here Brant tells the story of 'Hercules at the Cross-Roads', choosing between Virtue and Voluptas followed by Death. An illustration of the scene was added to the Latin translation of the work by Jacob Lochner, published in 1497, which shows Death behind the naked Voluptas. This latter rather poorly executed illustration is certainly not by Dürer, but it is possible that, before his return from the Upper Rhine to Nüremberg in May 1494, he left a rough sketch for the woodcut. Hercules who is shown reclining and dreaming resembles, even to details, 'The Knight of Thurn' in Dürer's woodcut of 1493. The Knight decides in his sleep to write his book for his daughters' sake.4 


\section{R. F. Timken-Zinkann}

Sebastian Brant's verses connecting Voluptas with Death may have been inspired by the biblical passage concerning the wages of sin; on the other hand, in 1494 Brant may have witnessed an unusually high rate of illness followed by death among the female and male followers of Voluptas in the cities of the Upper Rhine.

We know that these cities were the first places in Germany to be reached by syphilis. It is quite likely that the poorly trained and poorly equipped German physicians of the period only gradually came to recognize the affliction as a new and distinct illness. After all, what had not been described by Galen and the Moslem medical writers did not exist for the medical theory of the late fifteenth century. The infection is generally attributed to French soldiers returning via Basel and Strassburg after the siege of Naples by Charles VIII of France. However, this hypothesis is doubtful, since the French troops were delayed in Upper Italy after their abortive military adventure. Although syphilis was called the 'French illness' all over Europe except in France, it is quite possible that other travellers coming to the Upper Rhine were reponsible for its spread. This region was the hub of international travel from the areas bordering the Rhine to southern France, Spain, Switzerland and Italy. Shipping and travel by boat was the most comfortable mode of transportation from Mainz, Frankfurt, Würzburg, Cologne and the Netherlands. The Burgundian Port opened the most level overland route from Strassburg and Basel to southern France and Spain. Also the route to Switzerland and Italy via the Upper Rhine was the most comfortable from the western part of Germany and the eastern part of France. Merchants and their helpers, soldiers, pilgrims to Rome and Santiago and their escorts converged at this central region of communication. While it is not impossible that early returnees from the French expedition to Italy, stragglers, wounded and deserters were the first importers of the illness, travellers from many other parts of western Europe could have brought syphilis with them to the Upper Rhine.

In view of the fact that this region, as a point of convergence of European travel, was the focal point of infection for the German cities, and considering further the observation and identification of the illness in many German cities early in 1495, as well as assuming the generally-accepted hypothesis that Spanish sailors returning from Hispaniola in late 1492 imported the illness to Europe, it is not unreasonable to date the first cases of infection to Strassburg and Basel from the beginning of 1494, though they were not yet identified at that time as a new illness. Both the verses of Sebastian Brant and Dürer's drawing, 'The Pleasures of the World', could relate to such early and yet unidentified cases of syphilis. But there is no doubt that the first engravings discussed here were created at a time when the outbreak of syphilis and the mode of contagion were already well known.

Though Dürer was the first German artist whose life is fairly well documented, and though a prolific literary work was left by him, the autobiographical material is limited. The principal sources ${ }^{5}$ are a record of the history of his family, an autobiographical fragment of a 'memorial book', Dürer's letters to Pirckheimer from his second trip to Venice (1505-1507), a few other letters, and the extensive diary of his travels to the Netherlands in 1520 and 1521 . Only one outspoken reference to syphilis was made in his letter of 18 August 1506 from Venice to his humanist friend Willibald Pirckheimer. 'Give my compliments to our Prior and ask him to pray for me that 


\section{Some Aspects of Epidemics and German Art about 1500}

I may be saved, and especially from the French [i.e. syphilis], because I know nothing of which I am so much afraid, since nearly every man has it; it eats up many people so that they die thus.'

An inconclusive notice in Dürer's diary of his travels to the Netherlands deserves mention. During this journey he contracted a sickness which is believed with good reason to have been malaria, ${ }^{6}$ and he noted in the diary for 1521 that he spent one guilder for fourteen pieces of French wood; this refers to guaiac wood, imported into Europe by Spanish sailors from America as a specific against syphilis. However, this notice does not necessarily confirm a diagnosis of syphilis since guaiac was also used as a panacea. It should be noted that one guilder was a considerable amount at that time and that this expense was the largest mentioned in the diary for the many purchases of medicine reported by Dürer in 1521 .

We know that some members of the circle of German humanist friends with whom Dürer had contact through Pirckheimer, were early victims of syphilis, among them Conrad Celtis, first infected in 1496, and Ulrich von Hutten, The candour used by these humanists in discussing their affliction could hardly fail to impress Dürer with the threat of this illness.

It is a temptation to raise the question of whether or not Dürer himself, like so many German men of arts and letters of his time, was attacked by the disease. While German hero-worship has caused restraint of such conjecture, the puzzle of his married life has given rise to implicit question marks in the prolific German literature on Dürer. After his return to Nüremberg in May 1494, by an arrangement between his bride's father and his own father, on 7 July 1494 Dürer married, but left his wife a few weeks after the marriage for a trip to Italy, only to return after nine or ten months. We know of his itinerary only through his drawings and watercolours. He probably spent considerable time in Venice. A not undisputed publication by the foremost scholar examining documents referring to Dürer and his circle, ${ }^{7}$ assumes that Dürer travelled for several weeks from Upper Italy to Rome with Willibald Pirckheimer, his life-long friend and later a leading German humanist.

The sudden departure after the wedding has been explained by the outbreak of the plague in Nüremberg. ${ }^{8}$ While the exodus of a number of Nüremberg burghers at the time is well documented, it has always been questioned why Dürer, whose kindness and friendliness were attested by many contemporaries, left his wife in Nüremberg instead of seeking a refuge with her safe from the plague. It should be added that the marriage remained childless and not very happy, though we believe that Pirckheimer's accusations against Dürer's wife were exaggerated.

If we ascribe Dürer's sudden departure to a luetic infection contracted before his return to Nüremberg from the Upper Rhine, probably Strassburg, we must keep in mind that Dürer had already left for Nüremberg in May 1494. While it appears quite possible that unrecognized luetic cases existed at that time and place, such cases were probably still sporadic and did not appear in such numbers as at the beginning of 1495. It should be mentioned that Dürer's drawing of 1493 of a nude bathhouse attendant in Strassburg, the earliest known German drawing of a female nude from life, indicates that he was not averse to attending the houses which later proved to be hotbeds of luetic infection. 


\section{R. F. Timken-Zinkann}

The most puzzling question is raised by the medical interpretations which can be given to Dürer's self-portrait in the nude at the Museum in Weimar. Another, better known drawing of Dürer, dated between 1512 and 1514, was apparently done to consult an out-of-town physician. This latter pen drawing shows Dürer in the nude, half-length, with a loincloth. His right hand points to the spleen; an autograph inscription states that pains were felt at this spot.

The Weimar self-portrait probably dates from 1503, but is rarely reproduced in popular Dürer biographies. The figure is shown in three-quarter length. This very carefully executed pen and ink drawing is heightened with white on green grounded paper (Figures 9,10). The year of origin has been contested by some writers because Dürer looks rather old for a man of thirty-two. We know, however, from an inscription of a Dürer drawing 'Head of the dead Christ', dated 1503 in Dürer's handwriting, that Dürer was ill at the time. His features shown in his painted self-portrait of 1500 in Munich look only slightly younger, while those of his likeness inserted in the painting of the 'Feast of the Rose Garlands' of 1505 appear somewhat older.

The subject of this realistic drawing is unique and amazing not only for its time. The beautiful head shows the ear because the abundant hair, visible in other selfportraits, is partially covered by a hairnet; except for the pubic hair no traces of hair can be discerned on the body in spite of the careful and detailed execution of the drawing. Most strange is the fact that the genitals are drawn with great realism and that the contents of the right half of the scrotum appears to be unusually large. (Since we must assume that the self-portrait was done before a mirror, the side of the scrotum shown must be the right hand side.)

This raises the question of whether or not a pathological condition is shown to have existed. However, in the affirmative case a differential diagnosis based on this evidence would be impossible. Tumours, either malignant or in rare cases benign, or tuberculosis of the epidydimis would today be considered the most likely source of the symptom. The fact that Dürer survived the portrait by twenty-five years, however, may exclude a neoplastic tumour. Orchitis caused by mumps or gonorrhoea cannot be ruled out. A number of rare diseases causing similar symptoms are less probable.

Today, thanks to advances in venerology, fibrosis testis caused by syphilis is an extremely rare symptom; but until 1900 the luegenetic nature of swelling of the testis and epidydimis was a nearly axiomatic assumption in medical literature. The following translation of Oberndorfer's contribution to this question in the most reputable German handbook of the 1930s on special pathology ${ }^{9}$ may support this statement: 'Formerly [until 1900] the luetic origin of such swellings was considered nearly axiomatic. In $1900 \mathrm{v}$. Hanseman spoke of a redeeming act by Chiari when he denied the overpowering role of syphilis among the causes of Hodenschwielen.' (Though verbally translated 'callousness of the testis', further reference to this term in the chapter dealing with differential diagnosis makes it clear that the author meant all swellings of the testis and/or epidydimis.) Oberndorfer states in this context that it is, indeed, very difficult to distinguish the symptoms originating on a luetic basis from those 'not rare' cases of other origin.

Oberndorfer then quotes the results of statistical studies published by Loehlein, ${ }^{10}$ 


\section{Some Aspects of Epidemics and German Art about 1500}

Schlimpert ${ }^{11}$ and Simmonds ${ }^{12}$ in 1909 and 1910, a time when the Wassermann reaction made such statistics possible. The considerable advance in social hygiene and venerology at the beginning of the twentieth century should have reduced the incidence of syphilis, especially in its advanced stages, but these statistics showed luegenetic origin of the symptoms in 64 per cent of the cases. Another publication of Simmonds based on 1,000 sections of male corpses showed, however, only $37 \frac{1}{2}$ per cent indication of syphilitic causes of this symptom. It must be considered that not only the state of medical progress but also sociological conditions such as permissive attitudes in regard to promiscuity, proliferation of prostitution and its control and supervision, availability of prophylactic devices, hygienic information and other factors may have influenced the statistical results. At the time of the Weimar drawing, the statistical probability on the luetic origin of the symptom shown may have been considerably higher than in 1909/10.

The medical evaluation of the symptoms shown is, however, in no way uncontested. Today younger medical men have rarely seen cases of syphilogenetic testitis fibrosis. It has also been pointed out that unusually large testes of a non-pathogenic nature have been observed. Others lean towards a diagnosis of tuberculosis of the epidydimis. On the other hand, the experience of older venerologists and pathologists who have witnessed many cases of luegenetic testitis fibrosis cannot be overlooked, especially in conjunction with the statistical data of 1909/10 referred to above.

If a pathological enlargement of the testis or epidydimis is shown in the selfportrait, it is quite possible that other causes than syphilis accounted for this condition but that Dürer and his physicians, unable to make a differential diagnosis, assumed syphilis to be the cause of the symptom.

It is an open question whether or not Dürer's melancholic state of mind, his proneness to thoughts of catastrophe, illness or death would support the hypothesis of a syphilitic infection. The two famous syphilitic German humanists of the time were of a different state of mind. Conrad Celtis remained a gay blade in spite of two attacks of syphilis to which he succumbed at an early age, and Ulrich von Hutten, who underwent Spartan treatments by application of mercury and heat, still showed his fettle in writing to Willibald Pirckheimer, Gaudium est vivere. ${ }^{13}$

During the 1920s when the hypothesis of the 'syphilitic genius' was fairly popular among the intellectual world of continental Europe, the inconclusive evidence presented here might have led to a well-accepted belief that Dürer was another genius afflicted by this disease. We are now apt to be more cautious. We must recognize that scattered information opening certain possibilities does not constitute conclusive evidence. On the other hand, such a tentative evaluation of the Weimar drawing may open a new approach to the riddles of Dürer's life and to the understanding of the complexities and contradictions of his personality, ${ }^{14}$ though the limitations of such conclusions must be borne in mind. Even if the hypothesis should be correct, which probably may never be proved, it cannot fully explain Dürer the man and genius.

His personality may be described by a few traits. The energy of the boy of fifteen who succeeded in being apprenticed to a painter in spite of his father's wishes; the avoidance of quarrels at a time when polemics were nearly inevitable; the expressions 


\section{R. F. Timken-Zinkann}

of desperate sorrow at the death of his parents; the contradiction between his love for painstaking and detailed realism and his persevering search for numerical relations to establish the ideal proportions of the human figure; his interest in the freakish; his ambition to raise his social status; his narcissistic preoccupation with his own likeness; his self-identification with Christ; his religious anxieties; his sense of mission as the leader and educator of German art and his well-documented depressive moods prone to thoughts of illness and death, interspersed with occasional flurries of euphoria and ribaldry.

During the last century the prolific literature on Dürer over-emphasized every new aspect of his personality to the detriment of a balanced judgment. In contrast, Erwin Panofsky achieved in his Dürer biography ${ }^{15}$ a well-rounded picture of the whole Dürer in the currents and cross-currents of his time.

Dürer lived in a period of social, political, philosophical and religious upheaval at the end of the late Middle Ages and at the beginning of humanism and the reformation in Germany. Amidst all contradictions and struggles he became the foremost figure of German art by his own effort to realize the ideal of the divinely elected universal man. Many generations will continue to probe the essence of Dürer's personality from ever-new points of view.

\section{REFERENCES}

1. SuDHoff, K., Graphische und typographische Erstlinge der Syphilis-Literatur aus den Jahren 1495-1496, Munich, 1912.

2. Bloch, IwaN, Der Ursprung der Syphilis, Jena, 1901.

3. Brant, Sebastian, Das Narrenschiff, Basle, 1494.

4. The author believes that the theme showing the unconscious state of the Knight and of Hercules, while both were making a vital decision, was suggested by the chapter 'Septem vacationis genera' in Book XIII of Marsiglio Ficino's Theologia Platonica, Florence, 1482. Here Ficino exemplifies how contact with the Divine and intuition are experienced in various states of Vacatio mentis, the detachment of the soul. The first stage mentioned by Ficino is sleep. For the woodcut in the Latin edition of the Narrenschiff see also Erwin Panofsky, 'Hercules am Scheidewege', Studien der Bibliothek Warburg, 1930, 18.

5. RUPPRICH, H., Dürers schriftlicher Nachlass, vol. 1, Berlin, 1956.

6. FeDERSCHMmT, 'Albrecht Dürers Krankheit und Leiden', Münch. med. Woch., 1922, pp. 1123-24.

7. RUPPRICH, H., Willibald Pirckheimer und die erste Reise Dürers nach Italien, Vienna, 1930.

8. Flechsig, E., Albrecht Dürer, vol. 1, Berlin, 1928.

9. OBERNDORFER, S., 'Die inneren männlichen Geschlechtsorgane', pp. $657 \mathrm{ff}$., in HeNKE and LUBACH, Handbuch der pathologischen Anatomie, vol. 6, pt. 3, Berlin, 1931.

10. LokHLeIN, M., 'Uber die Bedeutung der Wassermannschen Reaktion an der Leiche', Verh. dt. path. Ges., 1909, 13, 92.

11. SCHLIMPERT, H., 'Beobachtungen bei der Wassermannschen Reaktion', Verh. dt. path. Ges., 1909, 13, 95.

12. Simmond, M., 'U'ber Fibrosis Testis', Virchows Arch. path. Anat. Physiol., 1910, 201, 108.

13. SPRINGER, B., Die genialen Syphilitiker, Berlin, 1926.

14. Lange-EIchbaum, W., and KURTH, W., Genie, Irrsinn und Ruhm, 6th ed., Munich, 1967 , pp. 250, 272. For a psychoanalytical discussion of Dürer, see: Alfred Winterstein, 'Dürers Melancholie im Lichte der Psychoanalyse', Imago, 1929, 15, 145-99.

15. Panofsky, E., Albrecht Dürer, Princeton, N.J., 1948. 